\title{
Angiotensin-(1-7) Prevents Skeletal Muscle Atrophy Induced by Transforming Growth Factor Type Beta (TGF- $\beta$ ) via Mas Receptor Activation
}

\author{
Johanna Ábrigo ${ }^{a, b}$ Felipe Simon ${ }^{a, b} \quad$ Daniel Cabrerac, $\quad$ Claudio Cabello-Verrugio ${ }^{a, b}$ \\ aDepartmento de Ciencias Biologicas, Facultad de Ciencias Biologicas and Facultad de Medicina, \\ Universidad Andres Bello, Santiago, '⿳亠丷厂巾 Millennium Institute on Immunology and Immunotherapy, \\ Santiago, 'Universidad Bernardo O Higgins, Facultad de Salud, Departamento de Ciencias Químicas \\ y Biológicas, Santiago, dDepartamento de Gastroenterología, Facultad de Medicina, Pontificia \\ Universidad Católica de Chile, Santiago, Chile
}

\section{Key Words}

Muscle wasting $\bullet$ TGF- $\beta \cdot \mathrm{ng}-(1-7) \cdot$ Mas receptor $\bullet$ MHC $\cdot$ MuRF-1

\begin{abstract}
Background: Transforming growth factor type beta 1 (TGF- $\beta 1$ ) produces skeletal muscle atrophy. Angiotensin-(1-7) (Ang-(1-7)), through the Mas receptor, prevents the skeletal muscle atrophy induced by sepsis, immobilization, or angiotensin II (Ang-II). However, the effect of Ang-(1-7) on muscle wasting induced by TGF- $\beta 1$ is unknown. Aim: To evaluate whether Ang-(1-7)/Mas receptor axis could prevent the skeletal muscle atrophy induced by TGF- $\beta 1$. Methods: This study assessed the atrophic effect of TGF- $\beta 1$ in $C_{2} C_{12}$ myotubes and mice in absence or presence of Ang-(1-7), and the receptor participation using A779, an antagonist of the Mas receptor. The levels of myosin heavy chain (MHC), polyubiquitination, and MuRF-1 were detected by western blot. Myotube diameter was also evaluated. In vivo analysis included the muscle strength, fibre diameter, MHC and MuRF-1 levels by western blot, and ROS levels by DCF probe detection. Results: The results showed that Ang-(1-7) prevented the increase in MuRF-1 and polyubiquitined protein levels, the decrease of MHC levels, the myotubes/ fibre diameter diminution, and the increased production of reactive oxygen species (ROS) induced by TGF- $\beta 1$. Utilizing A779 inhibited the anti-atrophic effect of Ang-(1-7). Conclusion: The preventive effect of Ang-(1-7) on skeletal muscle atrophy induced by TGF- $\beta 1$ is produced through inhibition of ROS production and proteasomal degradation of $\mathrm{MHC}$.
\end{abstract}

\section{Introduction}

Skeletal muscle atrophy is a pathological condition that affects skeletal muscle, producing loss of strength and muscle mass and leading to weakness [1, 2]. This condition can be produced by disuse, aging, bacterial infections, and chronic diseases [3-9]. There are 


\section{Cellular Physiology Cell Physiol Biochem 2016;40:27-38 \begin{tabular}{l|l|l} 
and BOI: 10.1159/000452522 & $\begin{array}{l}\text { C } 2016 \text { The Author(s). Published by S. Karger AG, Basel } \\
\text { www.karger.com/cpb }\end{array}$
\end{tabular} \\ Ábrigo et al.: Angiotensin (1-7) Prevents Muscle Wasting Induced by TGF- $\beta$}

different soluble factors that can be involved in the development of muscle atrophy, among them transforming growth factor type beta 1 (TGF- $\beta 1$ ) $[10,11]$. TGF- $\beta 1$ is a growth factor that regulates different processes in the cell such as proliferation, differentiation, regeneration, and apoptosis [12]. Studies indicate that the levels of TGF- $\beta 1$ primarily increase in cases of chronic diseases such as cancer, heart failure, or diabetes [13-18], and this increase could cause skeletal muscle atrophy [19]. Our recent research elucidated the mechanism involved in the atrophic effect of TGF- $\beta 1$ in skeletal muscle, which depends on an increase in reactive oxygen species (ROS) [11, 20]. We have shown the over-activation of ubiquitin-proteasome pathway (UPP), specifically an increase in the expression of E3 ubiquitin ligase MuRF-1. This occurs concomitant with a decrease in myosin heavy chain (MHC) protein levels and muscle fibre diameters.

Another important regulator of skeletal muscle mass is the renin-angiotensin system (RAS) [21-24]. Previous antecedents had demonstrated that Ang-II - a vasoactive peptide of the classical RAS axis - induces skeletal muscle atrophy by an over-activation of UPP and myonuclear apoptosis [25-27]. The alternative arm of RAS or non-classical RAS, is formed by ACE-2 that induces the synthesis of Ang-(1-7) peptide that acts via Mas receptor producing contrary effects than classical RAS $[24,28]$. In this context, our previous studies have shown that Ang-(1-7) prevents muscle atrophy induced by Ang-II, lipopolysaccharides, and disuse through the Mas receptor [29-32].

Based on this information, this study was designed to evaluate the effect of the Ang-(17)/Mas receptor axis on the TGF- $\beta 1$-dependent atrophic effect utilizing an in vitro and in vivo model of skeletal muscle atrophy.

\section{Materials and Methods}

\section{Animals studies}

Male C57BL/10J mice (12 weeks old) were used for the analysis. The mice were kept at room temperature on a 12:12 h light-dark cycle with access to food and water ad libitum [33]. Four groups of animals (with four mice per group) were randomly separated for the experiments: control, TGF- $\beta 1$ (10 ng) (Shenandoah Biotechnology Inc., PA, USA), Ang-(1-7) (100 ng/kg per min) (Sigma-Aldrich, MO, USA), and TGF- $\beta 1$ plus Ang-(1-7). Independent experiments were performed in triplicate. Mice under ketamine/ xylazine anaesthesia were injected with TGF- $\beta 1$ in the tibialis anterior (TA) muscle using the contralateral muscle as a control (injected with PBS) [34]. For the infusion of Ang-(1-7), two groups were implanted with osmotic micropumps (Alzet-Durect, CA, USA) 24 hours prior to TGF- $\beta 1$ injection following manufacturer instructions [34]. The mice were killed under anaesthesia $72 \mathrm{~h}$ post-injection, and the TA muscles were dissected, removed, rapidly frozen with isopentane, and stored at $-80{ }^{\circ} \mathrm{C}$ until use. All protocols were conducted in strict accordance with and under the formal approval of the Animal Ethics Committee of the Universidad Andrés Bello.

\section{Cell cultures}

The mouse skeletal muscle cell line $\mathrm{C}_{2} \mathrm{C}_{12}$ (American Type Culture Collection, VA, USA) were grown and used until passage 10 . The cells were differentiated into myotubes for five days, as described previously [35-39]. The myotubes were pre-incubated for $30 \mathrm{~min}$ with Ang-(1-7) (10 nM) in presence or absence of Mas Inhibitor A779 (10 $\mu \mathrm{M})$ (CPC Scientific, CA, USA) and then incubated with TGF- $\beta 1(10 \mathrm{ng} / \mathrm{ml})$ for the times indicated in each figure.

\section{Measurement of intracellular ROS levels}

The $\mathrm{C}_{2} \mathrm{C}_{12}$ myotubes were grown, differentiated, and treated on glass coverslips. After each treatment, the myotubes were washed with Hank's balanced salt solution (HBSS) and incubated with $10 \mu \mathrm{m}$ of the cellpermeant dye dichlorodihydrofluorescein (Invitrogen, CA, USA) for $30 \mathrm{~min}$ at $37^{\circ} \mathrm{C}$. Then, after duplicate washes with HBSS and one wash with phosphate-buffered saline (PBS), the myotubes were fixed with $4 \%$ paraformaldehyde for $10 \mathrm{~min}$ and washed with PBS. Nuclear staining was performed with $1 \mu \mathrm{g} / \mathrm{ml} \mathrm{Hoechst}$ 33258 in PBS for $10 \mathrm{~min}$. After rinsing the cells were mounted with a fluorescent mounting medium (Dako 


\section{Cellular Physiology Cell Physiol Biochem 2016;40:27-38

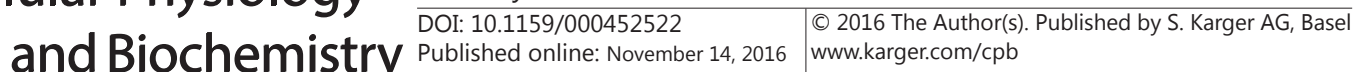 \\ Ábrigo et al.: Angiotensin (1-7) Prevents Muscle Wasting Induced by TGF- $\beta$}

Corporation, CA, USA), viewed, and photographed with the Motic BA310 epifluorescence microscope (Motic, Hong Kong).

\section{Western blot analysis}

After each treatment, the protein extracts of myotubes were obtained by homogenizing the sample in radioimmunoprecipitation assay buffer, and the protein extracts of TA were obtained by homogenizing the muscle with TRIS/EDTA buffer, with a cocktail of protease inhibitors and $1 \mathrm{mM}$ of phenylmethylsulfonyl fluoride in each case. Proteins were subjected to SDS-PAGE and transferred onto polyvinylidene difluoride membranes (EMD Millipore, Germany). The proteins were detected using the follow antibodies: mouse anti-MHC $(1: 3,000)$ (MF-20, University of Iowa Hybridoma Bank, IA, USA), rabbit anti-MuRF-1 (1:500) (ECM Biosciences, KY, USA), mouse anti-tubulin (1:5,000)(Santa Cruz Biotechnology, CA, USA). All immunoreactions were visualized by enhanced chemiluminescence (Thermo Fischer Scientific, MA, USA) using the FOTODYNE FOTO/Analyst Luminary Workstation Systems (FOTODYNE Inc., WI, USA).

\section{Contractile properties}

After treatment, the mice were anesthetized and the tibialis anterior (TA) muscles were removed and placed in a dish containing oxygenated Krebs-Ringer solution. Then the muscles were tied firmly with surgical silk, and transferred to a custom-built Plexiglas bath filled with oxygenated Krebs-Ringer solution thermostatically maintained at $37 \mathrm{C}$ for optimal oxygen diffusion. The muscles were tied to a MLT 1030/D force transducer (AD Instruments, Dunedin New Zealand) and further were stimulated by supramaximal square wave pulses using a S48 Stimulator (Grass Research Instruments, RI, USA), controlled and measured using a Power Lab 4/35 (AD Instruments) and computed with Lab Chart analysis software (AD Instruments). Maximum isometric tetanic force was determined as previously reported, by calculating in addition, the specific net force (force normalized per total muscle fiber cross-sectional area, $\mathrm{mN} / \mathrm{mm}^{2}$ ).

\section{Indirect Immunofluorescence}

The $\mathrm{C}_{2} \mathrm{C}_{12}$ cells were grown, differentiated for five days, and treated on plastic coverslips. Then, each treated myotubes was washed twice in ice-cold HBSS, fixed in 4\% paraformaldehyde, and permeabilized with $0.05 \%$ Triton X-100. Afterward, treatments were blocked for $1 \mathrm{~h}$ with a buffer containing $50 \mathrm{mM}$ Tris$\mathrm{HCl}(\mathrm{pH}$ of 7.7), $0.1 \mathrm{M} \mathrm{NaCl}$, and 2\% bovine serum albumin and incubated for $1 \mathrm{~h}$ with 1:100 mouse antiMHC in the same buffer. After antibody removal and several washes with HBSS, bound antibodies were detected by incubating the cells for $1 \mathrm{~h}$ with 1:500 affinity-purified Alexa Fluor dye-conjugated goat antimouse antibody (Life Technologies, CA, USA). Nuclear staining was performed with $1 \mu \mathrm{g} / \mathrm{ml}$ Hoechst 33258 in PBS for 10 min. After rinsing, the cells were mounted with a fluorescent mounting medium, viewed, and photographed with the Motic BA310 epifluorescence microscope.

\section{Wheat germ agglutinin staining}

Wheat germ agglutinin (WGA) staining labels glycoproteins at the sarcolemma [29, 31]. To stain the samples, freshly-frozen TA muscles were cryosectioned $(8 \mu \mathrm{m})$ and placed on glass slides. The samples were fixed in 4\% paraformaldehyde and incubated with Alexa-594-conjugated WGA (1:200) (Molecular Probes, OR, USA) and $1 \mu \mathrm{g} / \mathrm{ml}$ Hoechst 33258 in PBS. Triplicate PBS washes were performed between each step. After rinsing, the TA sections were mounted with a fluorescent mounting medium under glass coverslips, viewed, and photographed with the Motic BA310 epifluorescence microscope.

\section{Myotube/Fibre diameter determination and quantification}

Photographs obtained of immunofluorescent myotubes for MHC in different zones of the coverslip were used to obtain the myotube diameters. These measurements were determined through a blinded analysis with the ImageJ software (National Institutes of Health, MD, USA) of the images captured from each experimental condition. Myotube diameter was measured at three different points of the individual myotube, and then the values were averaged. Myotubes were defined as all multinucleated (containing three or more nuclei) cells positive for MHC stain. For the fibre diameter measurements, photographs obtained of TA sections stained with WGA were analysed from each experimental condition. The fibres were manually selected, and the minimal Feret's diameter of each fibre was quantified by the ImageJ software. 


\section{$\begin{array}{ll}\text { Cellular Physiology } & \text { Cell Physiol Biochem 2016;40:27-38 } \\ \text { DOI: 10.1159/000452522 } & \text { 2016 The Author(s). Published by S. Karger AG, Basel }\end{array}$

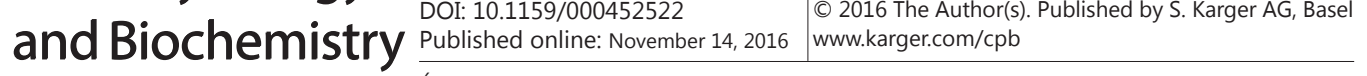 \\ Ábrigo et al.: Angiotensin (1-7) Prevents Muscle Wasting Induced by TGF- $\beta$}

Statistics

Data were analysed statistically using one-way analysis of variance with a post-hoc Bonferroni multiple-comparison test (Sigma Stat Systat Software, CA, USA). Differences were considered statistically significant at $\mathrm{P}<0.05$.

\section{Results}

Ang-(1-7)/Mas receptor axis prevents the atrophic effects induced by TGF- $\beta$ in C2C12 myotubes by averting the decrease in myotube diameter and MHC levels

The effects of Ang-(1-7) on the atrophic effect of TGF- $\beta 1$ on skeletal muscle were evaluated in $\mathrm{C}_{2} \mathrm{C}_{12}$ myotubes. First, myotube diameter was determined after pre-incubating myotubes with Ang-(1-7) for 30 min followed by a co-incubation with TGF- $\beta 1$ for $72 \mathrm{~h}$. Myotubes treated with TGF- $\beta 1$ were qualitatively smaller than control myotubes, but in the presence of Ang-(1-7) shrinkage was prevented and myotubes were similar in size to the control (Fig. 1A). The effect of Ang-(1-7) incubation depended on the Mas receptor, as demonstrated by the inhibition of the Ang-(1-7)-dependent anti-trophic effect when the Mas receptor antagonist A779 was used (Fig. 1A). Quantification of myotube diameters showed that TGF- $\beta 1$ treatment increased the proportion of myotubes with small diameters $([0-5 \mu \mathrm{m}]$ and $[5-10 \mu \mathrm{m}])$ and decreased the proportion with big diameters $([20-30 \mu \mathrm{m}]$ and $[30-40$ $\mu \mathrm{m}])$ compared to the control (Fig. 1B). However, the myotubes treated with TGF- $\beta 1$ in the presence of Ang-(1-7) showed a curve of myotube diameters similar to the control (Fig. 1B).

Fig. 1. The Ang-(17)/Mas receptor axis prevents TGF- $\beta 1$ induced decrease in diameters of myotubes (A) $\mathrm{C}_{2} \mathrm{C}_{12}$ myoblasts differentiated for five days (myotubes) were pre-incubated in absence or presence of Ang(1-7) (10 nM), A779 $(10 \mu \mathrm{M})$, or both for $30 \mathrm{~min}$, and then incubated with TGF- $\beta 1$ (10 ng/mL) for $72 \mathrm{~h}$. MHC was detected by indirect immunofluorescence assay (green). Nuclei were labelled with Hoechst staining (blue). The bar scale represents $100 \mu \mathrm{m}$. The myotube diameters from (A) were measured, quantified and plotted. The graphics

A
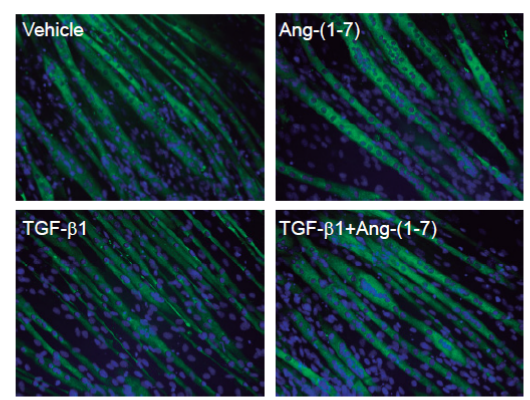

TGF- $\beta 1+$ Ang-(1-7)
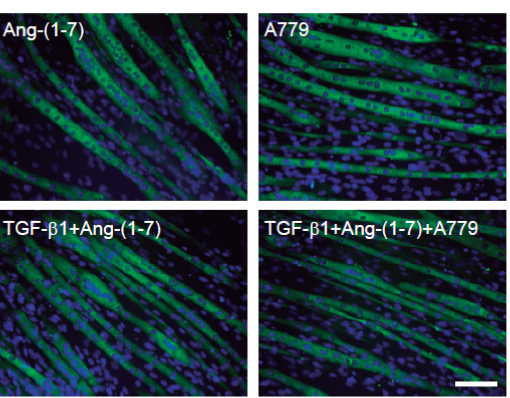

B

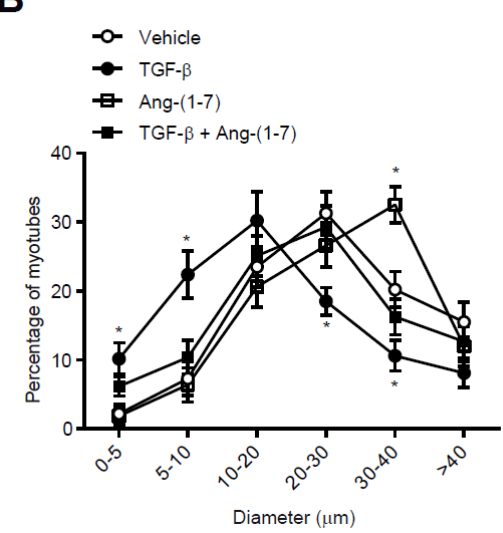

C

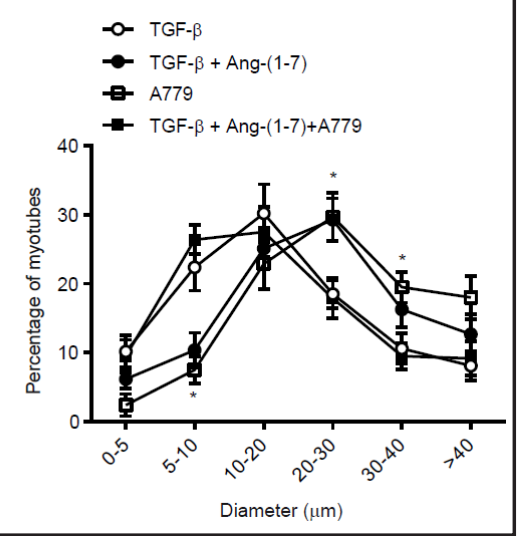

shows the effect of Ang-(1-7) (B), and the effect of Ang-(1-7) plus A779 (c) on the distribution of myotube diameters in presence or absence of TGF- $\beta 1$. The values are expressed as a percentage of the total myotubes and correspond to the mean \pm SD from three independent experiments ( ${ }^{*}, \mathrm{P}<0.05$ vs control). 


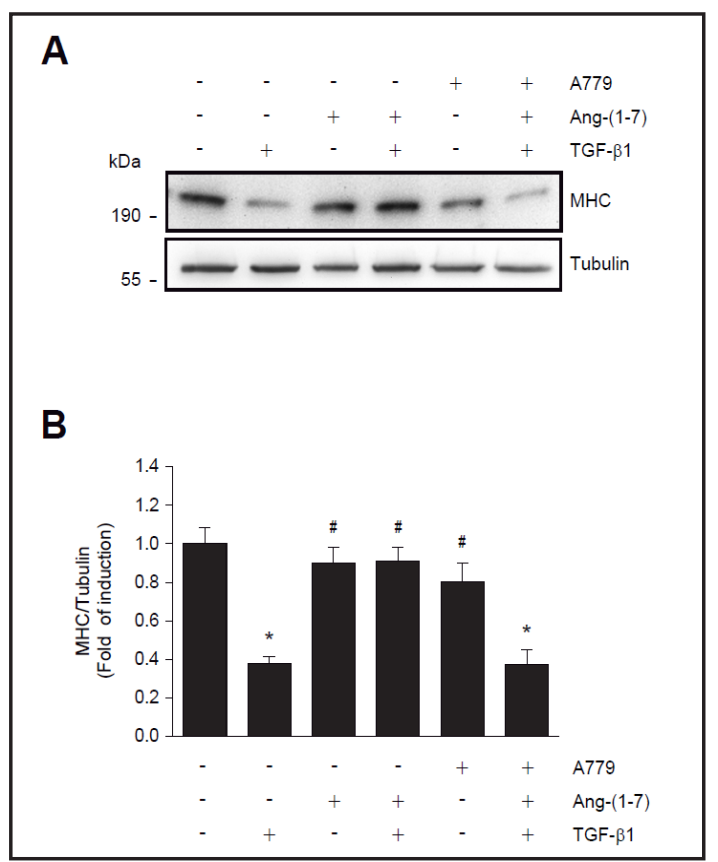

Fig. 2. Ang-(1-7) through the Mas receptor prevents TGF- $\beta 1$-induced decrease of MHC levels in myotubes. $\mathrm{C}_{2} \mathrm{C}_{12}$ myotubes were incubated with TGF- $\beta 1$ (10 ng/ $\mathrm{mL}$ ) for $72 \mathrm{~h}$ in presence or absence of Ang-(1-7) (10 $\mathrm{nM})$, A779 $(10 \mu \mathrm{M})$ (pre-incubated for $30 \mathrm{~min})$, or both. (A) The MHC protein levels were determined by Western blot analysis. Tubulin was used as loading control. Molecular weights are shown in $\mathrm{kDa}$. (B) Densitometric analysis for MHC protein levels with values normalized to tubulin and expressed as fold of induction relative to the control (myotubes without treatment). All values correspond to the mean \pm SD from three independent experiments $(*$, $\mathrm{P}<0.05$ vs control without treatment; ${ }^{\#}, \mathrm{P}<0.05$ vs TGF- $\beta 1$ treatment).

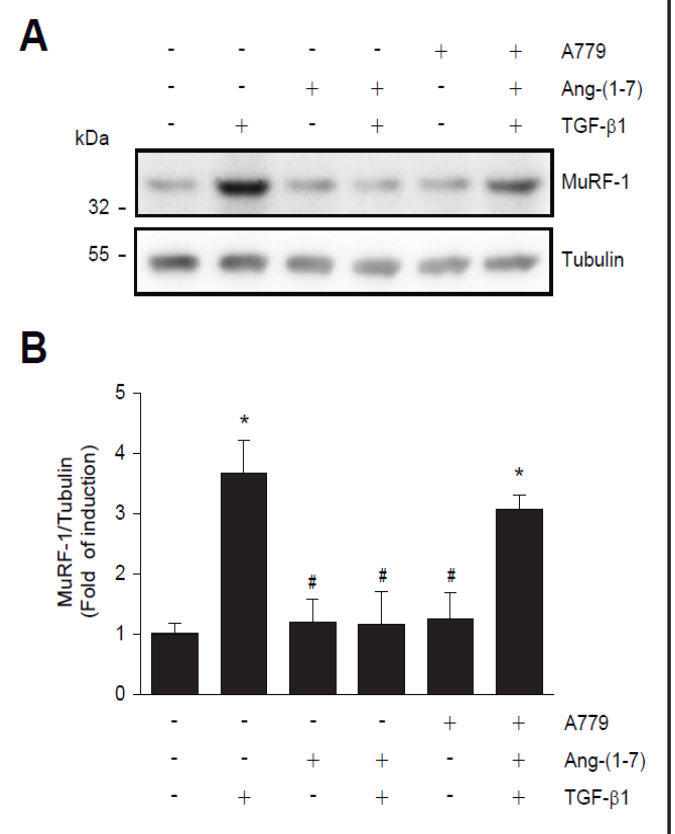

Fig. 3. Ang-(1-7) through the Mas receptor averts the rise in MuRF-1 levels induced by TGF- $\beta 1$ in $\mathrm{C}_{2} \mathrm{C}_{12}$ myotubes. $C_{2} C_{12}$ cells differentiated for five days were incubated with TGF- $\beta 1$ (10 ng/mL) for $48 \mathrm{~h}$ in presence or absence of Ang-(1-7) (10 nM), A779 $(10 \mu \mathrm{M})$ (pre-incubated for $30 \mathrm{~min})$, or both. (A) The protein levels of MuRF-1 were determined by Western blot analysis. Tubulin was used as loading control. Molecular weights are shown in kDa. (B) The graph shows the quantitative analysis for MuRF-1 levels with values normalized to tubulin and expressed as fold of induction relative to the control (myotubes without treatment). All values correspond to the mean \pm SD from three independent experiments ${ }^{*}$, $\mathrm{P}<0.05$ vs control without treatment; ${ }^{\#}, \mathrm{P}<0.05$ vs TGF- $\beta 1$ treatment).

Interestingly, Ang-(1-7) alone slightly displaced the curve of myotube diameters towards the right, with a significant difference in the range of 30-40 $\mu \mathrm{m}$ (Fig. 1B). Co-incubation with A779, a Mas receptor antagonist, in the presence of Ang-(1-7) and TGF- $\beta 1$ produced myotube diameters similar in size to those displayed in the presence of TGF- $\beta 1$ (Fig. 1C).

The levels of myofibrillar proteins, such as MHC, were assessed in the presence or absence of TGF- $\beta 1$, Ang-(1-7), and A779. The MHC levels decreased in the presence of TGF- $\beta 1$ treatment, displaying a 60\% drop in comparison to the control (Fig. 2A). Co-incubation of cells with TGF- $\beta 1$ and Ang-(1-7) displayed MHC levels similar to the control condition, while myotubes treated with Ang-(1-7), A779, and TGF- $\beta 1$ displayed results similar to those of cells treated with TGF- $\beta 1$ alone (Fig. 2A, B). These results indicate that the Ang-(1-7)/Mas receptor axis prevented the atrophic effect of TGF- $\beta 1$ induced in $\mathrm{C}_{2} \mathrm{C}_{12}$ myotubes.

Ang-(1-7), through the Mas receptor, prevents the over-activation of ubiquitin proteasome pathway (UPP) induced by TGF- $\beta 1$ in C2C12 myotubes

The UPP, the most studied catabolic pathway of sarcomere proteins such as MHC [4042 ], is over-activated in several types of skeletal muscle atrophy. Recently, TGF- $\beta 1$ was found 


\section{Cellular Physiology and Biochemistry

Fig. 4. The Ang-(1-7)/Mas receptor axis prevents an increase in the polyubiquitination of protein induced by TGF- $\beta 1$ in myotubes. $\mathrm{C}_{2} \mathrm{C}_{12}$ cells differentiated for five days (myotubes) were pre-incubated in absence or presence of Ang-(1-7) (10 nM), A779 (10 $\mu \mathrm{M})$, or both and then incubated with TGF- $\beta 1(10 \mathrm{ng} / \mathrm{mL})$ for $48 \mathrm{~h}$ as indicate by the figure. (A) The polyubiquitined protein levels were determined by Western blot analysis using tubulin as loading control. Molecular weights are shown in $\mathrm{kDa}$. (B) Densitometric analysis for polyubiquitined proteins levels with values normalized to tubulin and expressed as fold of induction relative to the control (myotubes without treatment). The values correspond to the mean \pm SD from three independent experiments ${ }^{*}$, $\mathrm{P}<0.05$ vs control without treatment; \#, $\mathrm{P}<0.05$ vs TGF- $\beta 1$ treatment).

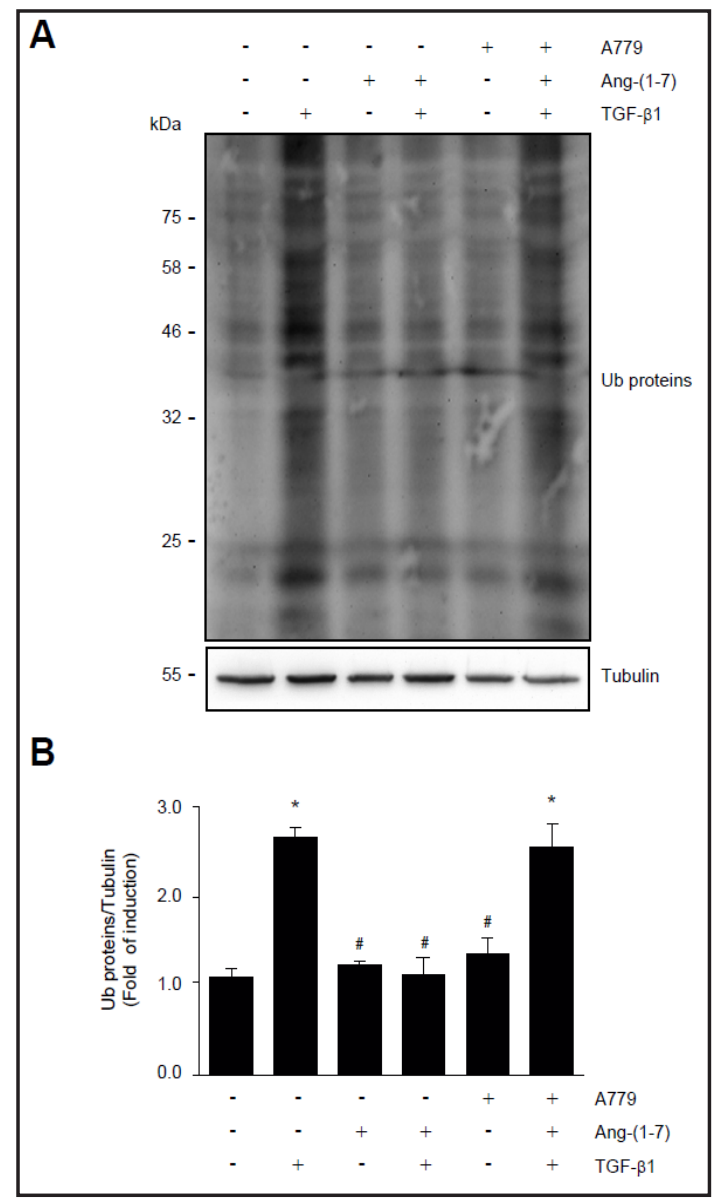

to produce an increase in the E3 ubiquitin ligase MuRF-1 in myotubes. The effect of Ang(1-7)/Mas axis on TGF- $\beta 1$-induced UPP over-activation was evaluated by determining the MuRF-1 levels and profile of the polyubiquitined protein. To accomplish this, myotubes were incubated in the presence or absence of Ang-(1-7), A779, and TGF- $\beta 1$ for $48 \mathrm{~h}$. Levels of MuRF-1 protein increased by 3.8 -fold due to TGF- $\beta 1$ incubation. In contrast, in the presence of Ang-(1-7) these levels decreased to amounts similar to the control, but co-incubation with A779 blocked the effect of Ang-(1-7) in the presence of TGF- $\beta 1$, allowing for a 3.1-fold rise in MuRF-1 levels (Fig. 3A, B).

The effect of Ang-(1-7) on the polyubiquitined proteins was similar to that of MuRF1. Polyubiquitined proteins increased by 2.7 -fold when incubated with TGF- $\beta 1$, and the increase was prevented by Ang-(1-7). In the presence of A779, the preventive effect of Ang(1-7) was impeded, and the levels of polyubiquitination were similar to those in samples with only TGF- $\beta 1$ (Fig. 4A, B).

Together, these results indicate that Ang-(1-7)/Mas axis prevented the over-activation of UPP induced by TGF- $\beta 1$ in $\mathrm{C}_{2} \mathrm{C}_{12}$ myotubes, specifically, the increase in MuRF- 1 expression and polyubiquitined proteins.

TGF- $\beta 1$-dependent ROS production is prevented by Ang-(1-7)/Mas receptor axis in C2C12 myotubes

Previously, we have demonstrated that ROS production is a key regulator in the skeletal muscle atrophy induced by TGF- $\beta 1$. To evaluate the effect of Ang-(1-7) on ROS induced by TGF- $\beta 1$, myotubes were co-incubated with TGF- $\beta 1$, Ang-(1-7), and A779, and the ROS levels were measured using the fluorescent dye CM-DCF (Fig. 5A). The DCF-positive myotubes were 


\section{Cellular Physiology Cell Physiol Biochem 2016;40:27-38

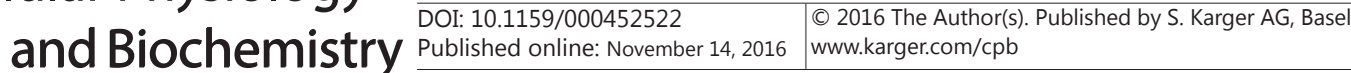 \\ Ábrigo et al.: Angiotensin (1-7) Prevents Muscle Wasting Induced by TGF- $\beta$}

Fig. 5. The increase of reactive oxygen species (ROS) induced by TGF- $\beta 1$ is prevented by Ang-(1-7) through the Mas receptor in myotubes. (A) $\mathrm{C}_{2} \mathrm{C}_{12}$ myotubes were incubated with TGF- $\beta 1$ (10 ng/mL) for $24 \mathrm{~h}$ in presence or absence of Ang-(1-7) (10 nM), A779 $(10 \mu \mathrm{M})$ (pre-incubated for $30 \mathrm{~min}$ ), or both. The ROS levels were then determined by loading the cells with a CM-DCF-DA probe, and the nuclei were labelled with Hoechst. Fluorescence was determined by microscopy. Scale bar represents $100 \mu \mathrm{m}$. (B) The graph shows the quantification of DCFpositive myotubes for the different treatments. The values are expressed as fold of induction relative to the myotubes without treatment and correspond to the mean \pm SD from three independent experiments ${ }^{*}, \mathrm{P}<$ 0.05 vs control without treatment; \#, $\mathrm{P}$ $<0.05$ vs TGF- $\beta 1$ treatment).

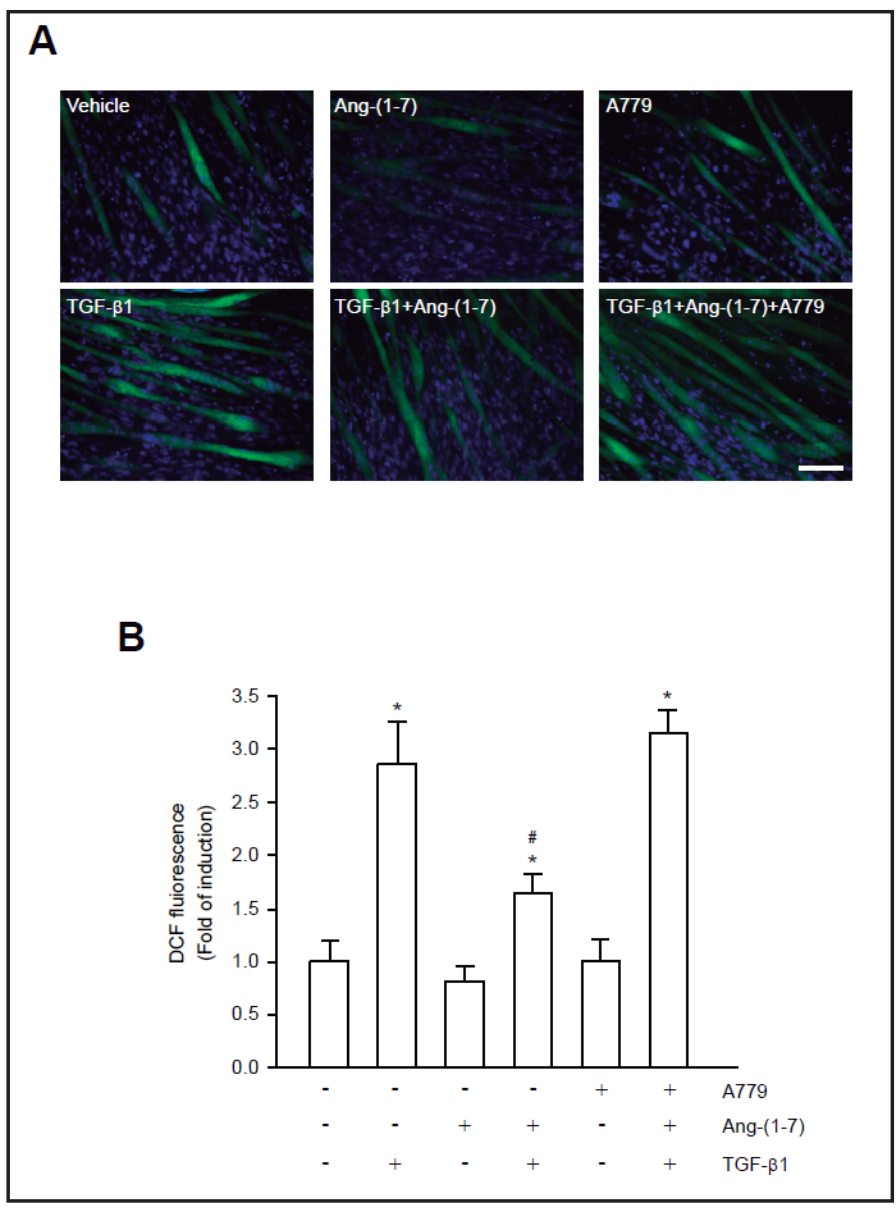

quantified for each condition. TGF- $\beta 1$-dependent ROS production (2.8-fold of induction relative to control) was partially decreased due to the effect of Ang-(1-7) (1.65-fold relative to control). The use of A779 hindered the effect of Ang-(1-7), and the ROS levels were similar to those of TGF- $\beta 1$ alone (Fig. 5B).

These results indicate that Ang-(1-7) through Mas receptor decreased the ROS production induced by TGF- $\beta 1$ in $\mathrm{C}_{2} \mathrm{C}_{12}$ myotubes.

Ang-(1-7) prevented the atrophic effect of TGF- $\beta 1$, specifically muscle strength, fibre diameter and myosin level diminution in the tibialis anterior muscle of mice.

We evaluated the effect of Ang-(1-7) on the decline in the muscle strength induced by TGF- $\beta$. The measures of isometric force showed that Ang-(1-7) is able to recover the decline in muscle strength produced by TGF- $\beta$ (Fig. 6 A). In a previous report, we showed that TGF- $\beta 1$ injected into TA muscle produces a diminution in the diameter of the fibres and decreases the MHC protein levels [11]. To test the anti-atrophic effect of Ang-(1-7) in this model, the peptide was systemically administered to mice that were then injected with TGF- $\beta 1$ in the TA. The results indicated that diminution in muscle fibre size induced by TGF- $\beta 1$ was prevented when Ang-(1-7) was administered (Fig. 6B). The TGF- $\beta 1$ injections produced a shift towards fibre of a lesser diameter than the control condition, while in the presence of Ang-(1-7) this effect was lost and fibre diameters were similar to the control condition (Fig. 6C). When the MHC levels were evaluated, Ang-(1-7)-treated samples did not display the decrease in MHC levels induced by TGF- $\beta 1$ (Fig. 6D, E).

These results show that the anti-atrophic effects of Ang-(1-7) were observable in an in vivo model of TGF- $\beta 1$-induced muscle wasting in mice. 


\section{\begin{tabular}{lll} 
Cellular Physiology & \multicolumn{1}{c}{ Cell Physiol Biochem 2016;40:27-38 } \\
DOI: 10.1159/000452522 & 02016 The Author(s). Published by S. Karger AG, Basel
\end{tabular}

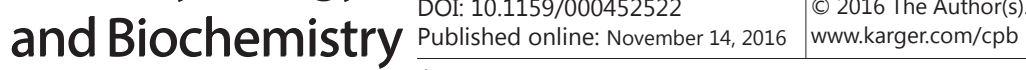 \\ Ábrigo et al.: Angiotensin (1-7) Prevents Muscle Wasting Induced by TGF- $\beta$}

Fig. 6. Ang-(1-7) prevents the decrease of the fibre diameters and MHC levels induced by TGF- $\beta 1$ in the tibialis anterior (TA) of mice. (A) TA muscles of male C57/ BL10 mice were injected with either PBS (control) or TGF- $\beta 1$ (10 ng) at day 1 and 3. To the correspondent group, osmotic micropumps with Ang-(1-7) (100 ng/kg per min) or vehicle were implanted $24 \mathrm{~h}$ prior to first injection with TGF- $\beta 1$. After 5 days of the first TGF- $\beta$ injection, muscles were excised and maximal isometric strength $(\mathrm{mN} / \mathrm{mm} 2)$ was evaluated. Values represent the mean \pm SD of triplicate independent experiments and are expressed as percentage of the net force relative to mice treated with vehicle and injected with PBS. In each experiment, three mice were used for each experimental condition ( $^{*}, \mathrm{P}<$ 0.05 vs control vehicle; $\#, \mathrm{P}<$ 0.05 vs TGF- $\beta 1$ vehicle). (B) TA

\section{A}
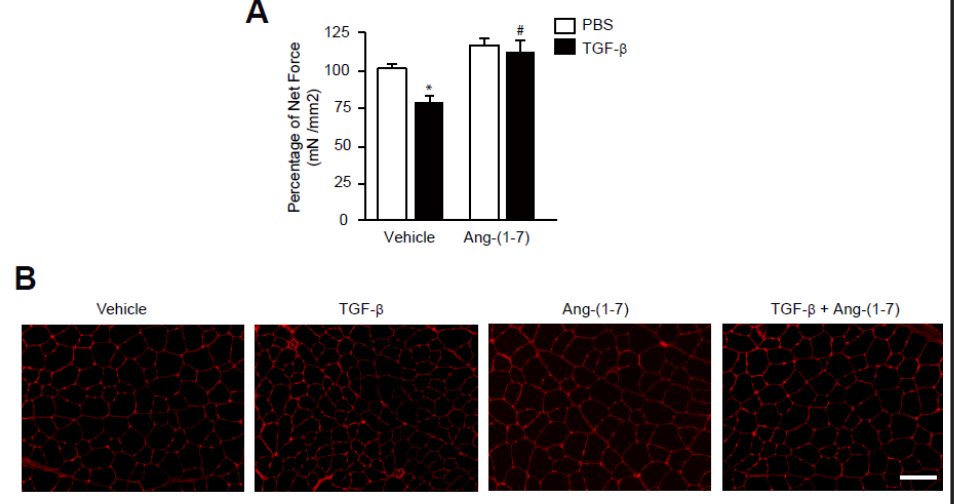

C

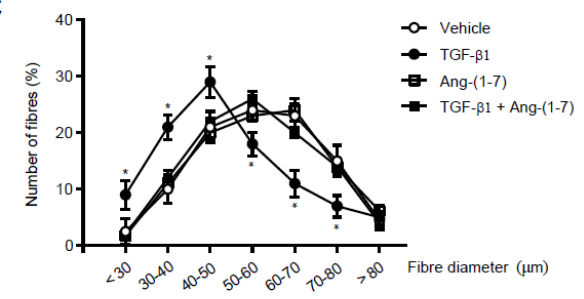

D

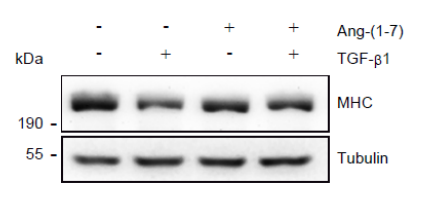

E

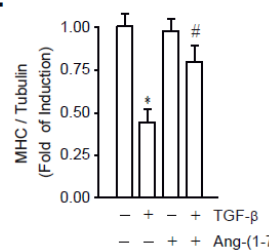

muscles of male C57/BL10 mice were injected with either PBS (control) or TGF- $\beta 1$ (10 ng) for once. To the correspondent group, osmotic micropumps with Ang-(1-7) (100 ng/kg per min) or vehicle were implanted $24 \mathrm{~h}$ prior to the injection with TGF- $\beta 1$. After $72 \mathrm{~h}$, the muscles were removed. Cryosections of TA muscles were stained with WGA and the fibre Feret's diameter was determined. The bar scale corresponds to $100 \mu \mathrm{m}$. Quantitative analysis for the fibre diameters is shown in (C). Values are expressed as the percentage of the total fibres quantified and correspond to the mean \pm SD from three independent experiments $(*, P<0.05)$. The MHC protein levels were determined by Western blot analysis. Tubulin was used as loading control. Molecular weights are shown in $\mathrm{kDa}$ (D). The quantitative analyses for MHC levels are shown (E). The values were normalized to tubulin and are expressed as fold of induction relative to the control incubated without TGF- $\beta 1$. Values correspond to the mean \pm SD from three independent experiments $(*, P<0.05$ vs control vehicle; \#, $\mathrm{P}<0.05$ vs TGF- $\beta 1$ vehicle).

\section{Discussion}

The present study demonstrates that Ang-(1-7)/Mas receptor axis averted the atrophic effects induced by TGF- $\beta 1$ in $\mathrm{C}_{2} \mathrm{C}_{12}$ myotubes. The results show that the use of Ang-(1-7) prevented an increase in ROS levels and the over-activation of UPP, specifically the increased MuRF-1 protein levels and polyubiquitined proteins. Concomitantly, Ang-(1-7) prevented the decrease in MHC protein levels and myotube and fibre diameters in skeletal muscle.

Despite that this study has several limitations, mainly by the in vitro experiments and the mechanisms that were derived from them, our findings must be corroborated in a pathological status in which an increase of TGF- $\beta$ can be observed.

The beneficial effects of Ang-(1-7) have been described in different tissues and cell types [43-48]. In skeletal muscle, previous research performed on rodent muscle wasting 


\section{Cellular Physiology Cell Physiol Biochem 2016;40:27-38

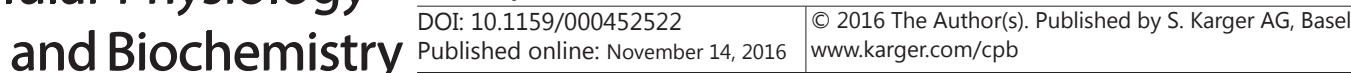 \\ Ábrigo et al.: Angiotensin (1-7) Prevents Muscle Wasting Induced by TGF- $\beta$}

induced by disuse [32], lipopolysaccharides [31], and Ang-II [29, 30], indicates that Ang-(17) prevents muscle atrophy through the Mas receptor. This study is the first to demonstrate the protective effect of Ang-(1-7) in muscle atrophy induced by TGF- $\beta 1$.

Our previous study establishes that one of the primary mechanisms involved in the development of skeletal muscle atrophy induced by TGF- $\beta 1$ is the increase in ROS production [11]. This study demonstrated that Ang-(1-7)/Mas axis prevented the rise of ROS levels induced by TGF- $\beta 1$ in $\mathrm{C}_{2} \mathrm{C}_{12}$ myotubes. These results concur with previous evidence indicating that Ang-(1-7) via the Mas receptor decreases oxidative stress in different cell types, such as adipocytes [49], cerebral endothelial cells [50], and, interestingly, in pathologies associated with skeletal muscle atrophy such as diabetes [51], cardiac failure [52], and hepatic damage [53]. Additionally, previously published results by us shows that Ang-(1-7)/Mas receptor prevents ROS induction by Ang-II in skeletal muscle cells [54]. Therefore, Ang-(1-7) could have an antioxidant effect in skeletal muscle atrophy conditions induced by TGF- $\beta 1$.

Among the main sources of intracellular ROS is NADPH oxidase (NOX) [55, 56]. Previous work indicates that the TGF- $\beta 1$-induced rise in ROS production is dependent on NOX in skeletal muscle cells [20]. Other groups demonstrate that Ang-(1-7) decreases mRNA levels of NOX in adipocytes [49] or the NOX activation [57, 58]. Based on this research, Ang-(1-7) could block the NOX-dependent ROS production. Further investigation is necessary in order to study this possible Ang-(1-7) effect.

An increase in TGF- $\beta 1$ levels as well as in its signalling is observed in various skeletal muscle disorders $[19,59-61]$. One of these is Duchenne muscular dystrophy, in which $m d x$ mice has serve as murine models [62]. Interestingly, the muscle wasting associated with $m d x$ mice is decreased by an Ang-(1-7) infusion that inhibits TGF- $\beta 1$ signalling; thus, reducing fibrosis and restoring muscle strength [34]. TGF- $\beta 1$ signaling also increases during muscle atrophy induced by Ang-II or disuse [63-66]. In these muscle wasting models, Ang-(1-7) displays an anti-atrophic effect evidenced by the prevention of decreases in muscle strength, UPP over-activation, and decreases in MHC levels [32, 54]. However, other complementary studies must be performed to evaluate the direct relation between the Ang-(1-7) mediated inhibition of TGF- $\beta 1$ signalling and the anti-atrophic effect in these models.

One of the possible mechanisms regulated by Ang-(1-7) is the signalling pathway activated by TGF- $\beta 1$. The canonical TGF- $\beta 1$ pathway is mediated by the phosphorylation of Smad2/3 proteins [67] and further transcription of target genes. In this pathway, Smad7 is an inhibitory protein, acting through negative feedback by blocking the Smad2/3 phosphorylation [67]. In dystrophic $m d x$ mice, previous research demonstrated that Ang-(17) increases Smad7 expression [34]. This study, we have demonstrated that TGF- $\beta 1$ induces the phosphorylation of both Smad proteins and that this pathway is involved in the atrophic effect induced by TGF- $\beta 1$ (unpublished result) in $\mathrm{C}_{2} \mathrm{C}_{12}$ myotubes. However, further studies are necessary to evaluate the possible participation of Smad7 on the anti-atrophic effect mediated by Ang-(1-7).

The present study shows that Ang-(1-7), through the Mas receptor, prevented the atrophic effects induced by TGF- $\beta 1$ in skeletal muscle cells and tissue. In this context, the clinical importance of our results is that could be extrapolated to diseases in which TGF- $\beta$ levels are increased (such as Duchenne muscular dystrophy) and evaluate the effect on muscle atrophy. Thus, Ang-(1-7) could be used as a therapeutic alternative for the treatment of skeletal muscle atrophy induced by different chronic diseases

\section{Acknowledgements}

This study was supported by research grants from the Association-Francaise Contre Les Myopathies [AFM 16670 (CCV)]; National Fund for Science \& Technology Development, [FONDECYT 1161646 (CCV), 1161288 (FS), 3140396 (DC)]; Millennium Institute on Immunology and Immunotherapy [P09-016-F (CCV-FS)]; and UNAB-DI [741-15/N (CCVFS)]. J. Ábrigo would like to thank Conicyt for providing a PhD Scholarship [21161353]. 


\section{Cellular Physiology Cell Physiol Biochem 2016;40:27-38 \begin{tabular}{ll|l} 
and Biochemistry Published online: November 14, 2016 & $\begin{array}{l}\text { (c) } 2016 \text { The Author(s). Published by S. Karger AG, Basel } \\
\text { www.karger.com/cpb }\end{array}$ \\
\hline
\end{tabular} \\ Ábrigo et al.: Angiotensin (1-7) Prevents Muscle Wasting Induced by TGF- $\beta$}

\section{Disclosure Statement}

The authors declare no conflict of interest.

\section{References}

1 Jackman RW, Kandarian SC: The molecular basis of skeletal muscle atrophy. Am J Physiol Cell Physiol 2004;287:C834-843.

2 Glass DJ: Skeletal muscle hypertrophy and atrophy signaling pathways. Int J Biochem Cell Biol 2005;37:1974-1984.

3 Benavides Damm T, Egli M: Calcium's role in mechanotransduction during muscle development. Cell Physiol Biochem 2014;33:249-272.

4 Zhu K, Yi J, Xiao Y, Lai Y, Song P, Zheng W, Jiao H, Fan J, Wu C, Chen D, Zhou J, Xiao G: Impaired bone homeostasis in amyotrophic lateral sclerosis mice with muscle atrophy. J Biol Chem 2015;290:8081-8094.

5 Cooney RN, Kimball SR, Vary TC: Regulation of skeletal muscle protein turnover during sepsis: mechanisms and mediators. Shock 1997;7:1-16.

6 Miro O, Pedrol E, Cebrian M, Masanes F, Casademont J, Mallolas J, Grau JM: Skeletal muscle studies in patients with HIV-related wasting syndrome. J Neurol Sci 1997;150:153-159.

7 Argiles JM, Busquets S, Felipe A, Lopez-Soriano FJ: Muscle wasting in cancer and ageing: cachexia versus sarcopenia. Adv Gerontol 2006;18:39-54.

8 Evans WJ, Morley JE, Argiles J, Bales C, Baracos V, Guttridge D, Jatoi A, Kalantar-Zadeh K, Lochs H, Mantovani G, Marks D, Mitch WE, Muscaritoli M, Najand A, Ponikowski P, Rossi Fanelli F, Schambelan M, Schols A, Schuster M, Thomas D, Wolfe R, Anker SD: Cachexia: a new definition. Clin Nutr 2008;27:793-799.

9 Tisdale MJ: Mechanisms of cancer cachexia. Physiol Rev 2009;89:381-410.

10 Mendias CL, Gumucio JP, Davis ME, Bromley CW, Davis CS, Brooks SV: Transforming growth factor-beta induces skeletal muscle atrophy and fibrosis through the induction of atrogin-1 and scleraxis. Muscle Nerve 2012;45:55-59.

11 Abrigo J, Rivera JC, Simon F, Cabrera D, Cabello-Verrugio C: Transforming growth factor type beta (TGFbeta) requires reactive oxygen species to induce skeletal muscle atrophy. Cell Signal 2016;28:366-376.

12 Cannaerts E, van de Beek G, Verstraeten A, Van Laer L, Loeys B: TGF-beta signalopathies as a paradigm for translational medicine. Eur J Med Genet 2015;58:695-703.

13 Gold LI: The role for transforming growth factor-beta (TGF-beta) in human cancer. Crit Rev Oncog 1999;10:303-360.

14 Roberts AB, Wakefield LM: The two faces of transforming growth factor beta in carcinogenesis. Proc Natl Acad Sci U S A 2003;100:8621-8623.

15 Massague J: TGFbeta in Cancer. Cell 2008;134:215-230.

16 Padua D, Massague J: Roles of TGFbeta in metastasis. Cell Res 2009;19:89-102.

17 Reeves WB, Andreoli TE: Transforming growth factor beta contributes to progressive diabetic nephropathy. Proc Natl Acad Sci U S A 2000;97:7667-7669.

18 Yadav H, Quijano C, Kamaraju AK, Gavrilova O, Malek R, Chen W, Zerfas P, Zhigang D, Wright EC, Stuelten C, Sun P, Lonning S, Skarulis M, Sumner AE, Finkel T, Rane SG: Protection from obesity and diabetes by blockade of TGF-beta/Smad3 signaling. Cell Metab 2011;14:67-79.

19 Burks TN, Cohn RD: Role of TGF-beta signaling in inherited and acquired myopathies. Skelet Muscle 2011;1:19.

20 Abrigo J, Morales MG, Simon F, Cabrera D, Di Capua G, Cabello-Verrugio C: Apocynin inhibits the upregulation of TGF-beta1 expression and ROS production induced by TGF-beta in skeletal muscle cells. Phytomedicine 2015;22:885-893.

21 Brink M, Wellen J, Delafontaine P: Angiotensin II causes weight loss and decreases circulating insulin-like growth factor I in rats through a pressor-independent mechanism. J Clin Invest 1996;97:2509-2516.

22 Cabello-Verrugio C, Cordova G, Salas JD: Angiotensin II: role in skeletal muscle atrophy. Curr Protein Pept Sci 2012;13:560-569.

23 Henriksen EJ, Prasannarong M: The role of the renin-angiotensin system in the development of insulin resistance in skeletal muscle. Mol Cell Endocrinol 2013;378:15-22.

24 Cabello-Verrugio C, Morales MG, Rivera JC, Cabrera D, Simon F: Renin-angiotensin system: an old player with novel functions in skeletal muscle. Med Res Rev 2015;35:437-463.

25 Libera LD, Zennaro R, Sandri M, Ambrosio GB, Vescovo G: Apoptosis and atrophy in rat slow skeletal muscles in chronic heart failure. Am J Physiol 1999;277:C982-986. 


\section{Cellular Physiology Cell Physiol Biochem 2016;40:27-38

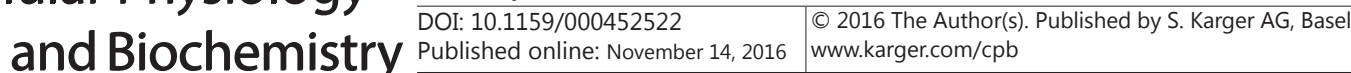 \\ Ábrigo et al.: Angiotensin (1-7) Prevents Muscle Wasting Induced by TGF- $\beta$}

26 Russell ST, Wyke SM, Tisdale MJ: Mechanism of induction of muscle protein degradation by angiotensin II. Cell Signal 2006;18:1087-1096.

27 Russell ST, Eley H, Tisdale MJ: Role of reactive oxygen species in protein degradation in murine myotubes induced by proteolysis-inducing factor and angiotensin II. Cell Signal 2007;19:1797-1806.

28 Liang B, Wang X, Zhang N, Yang H, Bai R, Liu M, Bian Y, Xiao C, Yang Z: Angiotensin-(1-7) Attenuates Angiotensin II-Induced ICAM-1, VCAM-1, and MCP-1 Expression via the MAS Receptor Through Suppression of P38 and NF-kappaB Pathways in HUVECs. Cell Physiol Biochem 2015;35:2472-2482.

29 Cisternas F, Morales MG, Meneses C, Simon F, Brandan E, Abrigo J, Vazquez Y, Cabello-Verrugio C: Angiotensin-(1-7) decreases skeletal muscle atrophy induced by angiotensin II through a Mas receptordependent mechanism. Clin Sci (Lond) 2015;128:307-319.

30 Meneses C, Morales MG, Abrigo J, Simon F, Brandan E, Cabello-Verrugio C: The angiotensin-(1-7)/Mas axis reduces myonuclear apoptosis during recovery from angiotensin II-induced skeletal muscle atrophy in mice. Pflugers Arch 2015;467:1975-1984.

31 Morales MG, Olguin H, Di Capua G, Brandan E, Simon F, Cabello-Verrugio C: Endotoxin-induced skeletal muscle wasting is prevented by angiotensin-(1-7) through a p38 MAPK-dependent mechanism. Clin Sci (Lond) 2015;129:461-476.

32 Morales MG, Abrigo J, Acuna MJ, Santos RA, Bader M, Brandan E, Simon F, Olguin H, Cabrera D, CabelloVerrugio C: Angiotensin-(1-7) attenuates disuse skeletal muscle atrophy in mice via its receptor, Mas. Dis Model Mech 2016;9:441-449.

33 Cabello-Verrugio C, Morales MG, Cabrera D, Vio CP, Brandan E: Angiotensin II receptor type 1 blockade decreases CTGF/CCN2-mediated damage and fibrosis in normal and dystrophic skeletal muscles. J Cell Mol Med 2012;16:752-764.

34 Acuna MJ, Pessina P, Olguin H, Cabrera D, Vio CP, Bader M, Munoz-Canoves P, Santos RA, Cabello-Verrugio C, Brandan E: Restoration of muscle strength in dystrophic muscle by angiotensin-1-7 through inhibition of TGF-beta signalling. Hum Mol Genet 2014;23:1237-1249.

35 Cabello-Verrugio C, Acuna MJ, Morales MG, Becerra A, Simon F, Brandan E: Fibrotic response induced by angiotensin-II requires NAD(P)H oxidase-induced reactive oxygen species (ROS) in skeletal muscle cells. Biochem Biophys Res Commun 2011;410:665-670.

36 Droguett R, Cabello-Verrugio C, Santander C, Brandan E: TGF-beta receptors, in a Smad-independent manner, are required for terminal skeletal muscle differentiation. Exp Cell Res 2010;316:2487-2503.

37 Doyle A, Zhang G, Abdel Fattah EA, Eissa NT, Li YP: Toll-like receptor 4 mediates lipopolysaccharideinduced muscle catabolism via coordinate activation of ubiquitin-proteasome and autophagy-lysosome pathways. FASEB J 2011;25:99-110.

38 Painemal P, Acuna MJ, Riquelme C, Brandan E, Cabello-Verrugio C: Transforming growth factor type beta 1 increases the expression of angiotensin II receptor type 2 by a SMAD- and p38 MAPK-dependent mechanism in skeletal muscle. Biofactors 2013;39:467-475.

39 Cofre C, Acuna MJ, Contreras O, Morales MG, Riquelme C, Cabello-Verrugio C, Brandan E: Transforming growth factor type-beta inhibits Mas receptor expression in fibroblasts but not in myoblasts or differentiated myotubes; Relevance to fibrosis associated to muscular dystrophies. Biofactors 2015;41:111120.

40 Eble DM, Spragia ML, Ferguson AG, Samarel AM: Sarcomeric myosin heavy chain is degraded by the proteasome. Cell Tissue Res 1999;296:541-548.

41 Bodine SC, Latres E, Baumhueter S, Lai VK, Nunez L, Clarke BA, Poueymirou WT, Panaro FJ, Na E, Dharmarajan K, Pan ZQ, Valenzuela DM, DeChiara TM, Stitt TN, Yancopoulos GD, Glass DJ: Identification of ubiquitin ligases required for skeletal muscle atrophy. Science 2001;294:1704-1708.

42 Sanders PM, Russell ST, Tisdale MJ: Angiotensin II directly induces muscle protein catabolism through the ubiquitin-proteasome proteolytic pathway and may play a role in cancer cachexia. Br J Cancer 2005;93:425-434.

43 Iwata M, Cowling RT, Gurantz D, Moore C, Zhang S, Yuan JX, Greenberg BH: Angiotensin-(1-7) binds to specific receptors on cardiac fibroblasts to initiate antifibrotic and antitrophic effects. Am J Physiol Heart Circ Physiol 2005;289:H2356-2363.

44 Marques FD, Melo MB, Souza LE, Irigoyen MC, Sinisterra RD, de Sousa FB, Savergnini SQ Braga VB, Ferreira AJ, Santos RA: Beneficial effects of long-term administration of an oral formulation of Angiotensin-(1-7) in infarcted rats. Int J Hypertens 2012;2012:795452.

45 Silveira KD, Barroso LC, Vieira AT, Cisalpino D, Lima CX, Bader M, Arantes RM, Dos Santos RA, Simoes eSAC, Teixeira MM: Beneficial effects of the activation of the angiotensin-(1-7) MAS receptor in a murine model of adriamycin-induced nephropathy. PLoS One 2013;8:e66082. 


\section{Cellular Physiology Cell Physiol Biochem 2016;40:27-38

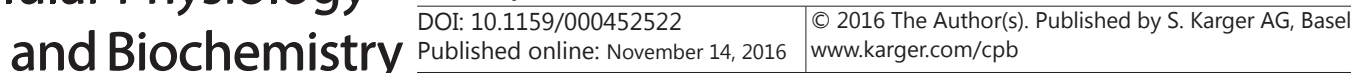 \\ Ábrigo et al.: Angiotensin (1-7) Prevents Muscle Wasting Induced by TGF- $\beta$}

46 Mori J, Patel VB, Ramprasath T, Alrob OA, DesAulniers J, Scholey JW, Lopaschuk GD, Oudit GY: Angiotensin 1-7 mediates renoprotection against diabetic nephropathy by reducing oxidative stress, inflammation, and lipotoxicity. Am J Physiol Renal Physiol 2014;306:F812-821.

47 de Almeida PW, Melo MB, Lima Rde F, Gavioli M, Santiago NM, Greco L, Jesus IC, Nocchi E, Parreira A, Alves MN, Mitraud L, Resende RR, Campagnole-Santos MJ, Dos Santos RA, Guatimosim S: Beneficial effects of angiotensin-(1-7) against deoxycorticosterone acetate-induced diastolic dysfunction occur independently of changes in blood pressure. Hypertension 2015;66:389-395.

48 Papinska AM, Mordwinkin NM, Meeks CJ, Jadhav SS, Rodgers KE: Angiotensin-(1-7) administration benefits cardiac, renal and progenitor cell function in db/db mice. Br J Pharmacol 2015;

49 Liu C, Lv XH, Li HX, Cao X, Zhang F, Wang L, Yu M, Yang JK: Angiotensin-(1-7) suppresses oxidative stress and improves glucose uptake via Mas receptor in adipocytes. Acta Diabetol 2012;49:291-299.

50 Xiao X, Zhang C, Ma X, Miao H, Wang J, Liu L, Chen S, Zeng R, Chen Y, Bihl JC: Angiotensin-(1-7) counteracts angiotensin II-induced dysfunction in cerebral endothelial cells via modulating Nox2/ROS and PI3K/NO pathways. Exp Cell Res 2015;336:58-65.

51 Zhang Y, Liu J, Luo JY, Tian XY, Cheang WS, Xu J, Lau CW, Wang L, Wong WT, Wong CM, Lan HY, Yao X, Raizada MK, Huang Y: Upregulation of Angiotensin (1-7)-Mediated Signaling Preserves Endothelial Function Through Reducing Oxidative Stress in Diabetes. Antioxid Redox Signal 2015;23:880-892.

52 Zhong J, Basu R, Guo D, Chow FL, Byrns S, Schuster M, Loibner H, Wang XH, Penninger JM, Kassiri Z, Oudit GY: Angiotensin-converting enzyme 2 suppresses pathological hypertrophy, myocardial fibrosis, and cardiac dysfunction. Circulation 2010;122:717-728, 718 p following 728.

53 Cai SM, Yang RQ, Li Y, Ning ZW, Zhang LL, Zhou GS, Luo W, Li DH, Chen Y, Pan MX, Li X: Angiotensin-(1-7) Improves Liver Fibrosis by Regulating the NLRP3 Inflammasome via Redox Balance Modulation. Antioxid Redox Signal 2016;

54 Morales MG, Abrigo J, Meneses C, Simon F, Cisternas F, Rivera JC, Vazquez Y, Cabello-Verrugio C: The Ang(1-7)/Mas-1 axis attenuates the expression and signalling of TGF-beta1 induced by AngII in mouse skeletal muscle. Clin Sci (Lond) 2014;127:251-264.

55 Bedard K, Krause KH: The NOX family of ROS-generating NADPH oxidases: physiology and pathophysiology. Physiol Rev 2007;87:245-313.

56 Jiang F, Zhang Y, Dusting GJ: NADPH oxidase-mediated redox signaling: roles in cellular stress response, stress tolerance, and tissue repair. Pharmacol Rev 2011;63:218-242.

57 Benter IF, Yousif MH, Dhaunsi GS, Kaur J, Chappell MC, Diz DI: Angiotensin-(1-7) prevents activation of NADPH oxidase and renal vascular dysfunction in diabetic hypertensive rats. Am J Nephrol 2008;28:25-33.

58 Yousif MH, Dhaunsi GS, Makki BM, Qabazard BA, Akhtar S, Benter IF: Characterization of Angiotensin-(1-7) effects on the cardiovascular system in an experimental model of type-1 diabetes. Pharmacol Res 2012;66:269-275.

59 Kollias HD, McDermott JC: Transforming growth factor-beta and myostatin signaling in skeletal muscle. J Appl Physiol (1985) 2008;104:579-587.

60 Bernasconi P, Di Blasi C, Mora M, Morandi L, Galbiati S, Confalonieri P, Cornelio F, Mantegazza R: Transforming growth factor-beta1 and fibrosis in congenital muscular dystrophies. Neuromuscul Disord 1999;9:28-33.

61 Ishitobi M, Haginoya K, Zhao Y, Ohnuma A, Minato J, Yanagisawa T, Tanabu M, Kikuchi M, Iinuma K: Elevated plasma levels of transforming growth factor beta1 in patients with muscular dystrophy. Neuroreport 2000;11:4033-4035.

62 Chen YW, Nagaraju K, Bakay M, McIntyre O, Rawat R, Shi R, Hoffman EP: Early onset of inflammation and later involvement of TGFbeta in Duchenne muscular dystrophy. Neurology 2005;65:826-834.

63 Morales MG, Vazquez Y, Acuna MJ, Rivera JC, Simon F, Salas JD, Alvarez Ruf J, Brandan E, Cabello-Verrugio C: Angiotensin II-induced pro-fibrotic effects require p38MAPK activity and transforming growth factor beta 1 expression in skeletal muscle cells. Int J Biochem Cell Biol 2012;44:1993-2002.

64 Morris RT, Spangenburg EE, Booth FW: Responsiveness of cell signaling pathways during the failed 15-day regrowth of aged skeletal muscle. J Appl Physiol (1985) 2004;96:398-404.

65 Zhang P, Chen X, Fan M: Signaling mechanisms involved in disuse muscle atrophy. Med Hypotheses 2007;69:310-321.

66 Burks TN, Andres-Mateos E, Marx R, Mejias R, Van Erp C, Simmers JL, Walston JD, Ward CW, Cohn RD: Losartan restores skeletal muscle remodeling and protects against disuse atrophy in sarcopenia. Sci Transl Med 2011;3:82ra37.

67 Nakao A, Afrakhte M, Moren A, Nakayama T, Christian JL, Heuchel R, Itoh S, Kawabata M, Heldin NE, Heldin $\mathrm{CH}$, ten Dijke P: Identification of Smad7, a TGFbeta-inducible antagonist of TGF-beta signalling. Nature 1997;389:631-635. 